\title{
How the Negative Stigma Associated with AIDS Affects Sufferers' Trustworthiness
}

\author{
Stephen Rice ${ }^{1}$, Joshua Sandry ${ }^{1} \&$ Jessica Richardson ${ }^{1}$ \\ ${ }^{1}$ Department of Psychology, New Mexico State University, Las Cruces, New Mexico, USA \\ Correspondence: Stephen Rice, Department of Psychology, New Mexico State University, Las Cruces, NM, \\ USA. Tel: 1-575-646-2502. E-mail: scrice67@gmail.com
}

Received: June 1, 2012 Accepted: July 4, 2012 Online Published: July 16, 2012

doi:10.5539/res.v4n4p54 URL: http://dx.doi.org/10.5539/res.v4n4p54

\begin{abstract}
Trust is foundational for social and healthcare relationships. Stigma associated with AIDS may affect evaluations of trustworthiness in AIDS sufferers. Participants evaluated the trustworthiness of someone described as being honest, dishonest, or having AIDS. The individual described as having AIDS was judged as untrustworthy as the individual described as being dishonest. In a follow-up experiment, the individual was described as being honest, dishonest, contracting AIDS via heterosexual sex, via male-to-male sexual intercourse, or via a blood transfusion. Someone contracting AIDS from male-to-male sexual intercourse was judged as untrustworthy as a dishonest person and more untrustworthy than individuals in the other conditions.
\end{abstract}

Keywords: AIDS, HIV, trust, disability, diversity

\section{Introduction}

Since the first few cases of HIV/AIDS surfaced in the early 1980s the scientific community has spent a large amount of time, money, and resources investigating the causes and treatments. A substantial amount of research has also been conducted in the behavioral sciences, investigating, among other things, the stigma associated with people who have HIV/AIDS and the related impact of stigma and discrimination on HIV/AIDS sufferers (Mahajan et al., 2008). In this paper, we argue that the negativity of the stigma associated with HIV/AIDS may transfer over to other psychological constructs, such as trust.

While there are many theories that have been used to assess behaviors of AIDS sufferers, including the Health Belief Model (Rosenstock, 1966, 1974), and Theory of Reasoned Action/Planned Behavior (Ajzen \& Fishbein, 1980; Fishbein \& Ajzen, 1975), these theories focus on predicting how people will engage in health related behaviors via beliefs, attitudes, subjective norms, etc. The goal of our study is not to assess health seeking behaviors of AIDS sufferers, but rather to examine judgments about AIDS sufferers.

The present paper focuses largely on the stigma associated with HIV/AIDS as well as people's trust perceptions of these same individuals. A stigmatized person is someone "whose social identity or membership in some social category, calls into question his or her full humanity - the person is devalued, spoiled or flawed in the eyes of others" (p. 504, Crocker, Major, \& Steele, 1998). Stigma can be focused at many different groups of people including the handicapped, the overweight, the unattractive, different races, etc. (Berschid \& Walster, 1974; Farina, 1982; Harris, Harris, \& Bocher, 1982; Newman, 1976). Those who are being stigmatized may end up being undervalued (Crocker, Cornwell, \& Major, 1993) which can result in various economic and social disadvantages (Crocker \& Major, 1989; Crocker, Voelkl, Testa, \& Major, 1991; Jones, Farina, Hastorf, Markus, Miller \& Scott, 1984).

Typically in the literature on HIV/AIDS, stigma is referred to as a mark of disgrace (Mahajan et al.; Link, 2001). People with HIV/AIDS have to learn how to cope with the detrimental side effects of stigma (Molero, Fuster, Jetten \& Moriano, 2011). Additionally, HIV/AIDS stigma has been correlated to depression, post-traumatic stress disorder, sexual risk-taking, (Preston, D’Augelli, Kassab, \& Starks, 2007; Simbayi, Kalichman, Strebel, Cloete, Henda, \& Mqeketo, 2007; Vanable, Carey, Blaire, \& Littlewood, 2006; Whetten, Reif, Whetten, \& Murphy-McMillan, 2008) and a reduced likelihood of individuals with HIV/AIDS to take their medication (Vanable et al., 2006; Whetten et al., 2008).

In addition to the aforementioned negative effects, stigma has also been shown to disrupt interpersonal 
relationships. Due to the undervaluing effect of stigma, the potential for diminished relationships between people with HIV/AIDS and those without the disease is increased. Sadly, a growing trend of social isolation has resulted from the stigma. One study showed that in addition to factors associated with diminished status, one of the major dimensions of stigma related to HIV/AIDS was separation from others (Bresnahan, \& Zhuanng, 2011). This suggests that in addition to devaluing of the stigmatized group, deficits in relationships are also a major consequence. This phenomenon can be seen in research showing that older adults face isolation due to many different factors including not wanting to be a burden to others and feeling that family and friends are unavailable (Schrimshow, \& Siegel, 2003). Likewise, increased levels of avoidant behavior and related depression have been identified in studies of individuals with HIV/AIDS (Gore-Folton, Koopman, Spiegel, Vosvick, Brondino, \& Winningham, 2006).

This detriment to interpersonal relationships is an important consideration because relationships and their associated characteristics have important benefits for mental and physical health. Research has shown that among couples where one partner has a chronic illness, communication about the illness is important for the well-being of both individuals of the couple (Arden-Close, Moss-Morris, Dennison, Bayne, \& Gidron, 2010). Furthermore, additional research has shown that disclosing emotional content related to having AIDS and processing the trauma associated with the diagnosis actually helped to improve HIV/AIDS patients' immune responses and physical health (O'Cleirigh, Ironson, Fletcher, \& Schneiderman, 2008). Importantly, social support, among other factors, has also been shown to reduce sexual risk taking behavior in individuals with HIV/AIDS (Gore-Felton, Koopman, Turner-Cobb, Duran, Israelski, \& Spiegel, 2002). This reduction in sexual risk taking in turn helps to reduce transmission of the disease. Whereas the negative effects of stigma on interpersonal relationships have been identified, one related dimension that has not been as readily studied is how the trustworthiness of HIV/AIDS patients is affected by the stigma.

\subsection{Trust}

Trust is a major facet of interpersonal relationship formation and maintenance. Because of the fallout associated with HIV/AIDS stigma, it is possible that stigma associated with HIV/AIDS may also result in onlookers perceiving people with the disease as being deficient in other psychological constructs, such as trustworthiness. Trust is a construct that has been investigated extensively in psychology (Lewicki \& Wiethoff, 2000; Messick, 1983; Miller \& Rempel, 2004; Rice, Trafimow, Hunt, \& Sandry, 2010; Baier, 1994), business and management (Anderson \& Thompson, 2004; Butler, 1991; Nugent \& Abolafia, 2006; Rotte, Chandrashekaran, Tax, \& Grewal, 2006; Weber, Malhotra, \& Murnighan, 2005) as well as applied settings (Choi, 2006; Dixon \& Wickens, 2006; Dixon, Wickens, \& McCarley, 2007; Keller \& Rice, 2010; Rice, 2009; Rice, Trafimow, Clayton, \& Hunt, 2008; Rice \& McCarley, in press; Rosen, 1977). Interpersonal trust is linked to relationships in many different areas and as trust diminishes, social relationships may become negatively affected (Rotter, 1980).

Trust can be defined in a number of ways; confidence in another person's choices related to risky situations (Lewicki \& Bunker, 1995; McAllister, 1995) or the expectation of altruistic behavior for the group (Offe, 1999). Interestingly, when there is no or little information about a person, people will still often initially trust a stranger (Stolle, 2002; Uslaner, 2002; Whiteley, 1999; Yamagishi \& Yamagishi, 1994); however, when various information about the individual is presented, trust in the person can be unpredictable (Carter \& Weber, 2010; Deutsch, 1960; Putnam, 2000; Rotter, 1971; Wrightsman, 1966).

In the HIV/AIDS literature, trust has been explored to various degrees. A growing body of literature has explored the amount of trust, or more appropriately, distrust that people have in the medical community. Some research based on interviews with predominantly African-American patients revealed that fear and stigma associated with HIV/AIDS diminished the likelihood of being tested. Additionally, there was a large amount of distrust related to information about HIV/AIDS and information coming from the government; for example, there was a belief in a conspiracy that an AIDS cure existed but was withheld by pharmaceutical companies and the government for financial reasons. This was more common with male respondents (Hutchinson, Corbie-Smith, Thomas, Mohanan $\&$ del Rio, 2004). Some of this fear and distrust may be a result of African-Americans receiving inadequate care compared to Caucasians (Bach, Pham, Schrag, Tate, \& Hargraves, 2004). On the other hand, when trust is high, the number of doctor visits, likelihood of taking medication, and overall health is higher than when trust is low (Whetten, Leserman, Whetten, Ostermann, Thielman, Sqartz, \& Stangl, 2006). The level of trust seems to be a reasonable predictor of testing, prevention, and care.

Clearly, HIV/AIDS patients' lack of trust is a huge problem for HIV/AIDS testing, prevention, and care. Something that has not been researched - to our knowledge - is how trustworthy other people view HIV/AIDS sufferers. If interpersonal trust suffers because someone has HIV/AIDS it may result in unfair treatment and 
discrimination in many different social environments or contexts. In fact, some have suggested that distrust in a particular culture can have devastating effects including the degradation of social networks, loss of cooperation (Axelrod, 1984; Coleman, 1990), and the development of negative attitudes, stereotypes and prejudice (Sztompka, 1997). The large amount of stigma associated with HIV/AIDS may transfer to the level of trust that people have in an individual who has AIDS. It is important to empirically investigate how stigma associated with AIDS impacts the level of trust that people have in others with the disease.

\subsection{Current Study}

The current study involved two experiments. In the first experiment, we presented participants with a person named Joe who was either described as Honest, Dishonest, or had AIDS. In a follow-up experiment, Joe was again either Honest or Dishonest; however, how he contracted AIDS was manipulated in three ways a) via gay intercourse, b) via heterosexual intercourse, or c) via a blood transfusion. The goal of both experiments was to compare how a given personality trait (Honest or Dishonest) and a physical disease (AIDS) affected trustworthiness ratings about Joe. We hypothesized across both experiments that Joe would be penalized for having AIDS, and that the method by which he contracted AIDS would have an impact on how much he was penalized.

\section{Experiment 1}

\subsection{Introduction}

In Experiment 1, different participants were presented with no information (control group) about Joe, information that Joe is Honest or Dishonest, or information that Joe has AIDS. After participants read the information about Joe, they made a rating regarding how trustworthy they thought Joe was. We hypothesized that because of the stigma associated with AIDS, Joe would be rated as less trustworthy when he has AIDS than when there was no information about him or when he was described as Honest

\subsection{Methods}

\subsubsection{Participants}

Eighty undergraduate students from a large southwestern university participated in the experiment for course credit. The mean age was $20.70(\mathrm{SD}=2.26)$.

\subsubsection{Materials and Stimuli}

In a questionnaire format, participants were given the following four scenarios about an undergraduate student named Joe: a) Joe is an Honest person; b) There is no information about Joe; c) Joe has AIDS; and d) Joe is a Dishonest person. Participants rated the trustworthiness of Joe on a Likert scale of -3 (extremely untrustworthy) to +3 (extremely trustworthy). They were allowed to put a neutral value of zero $(0)$ if they wished.

\subsubsection{Design}

Participants were randomly divided into four different groups, employing a between-participants design. Each group received one of the four scenarios.

\subsection{Results}

A one-way ANOVA was used to determine differences between the 4 conditions. Follow-up t-tests were subjected to a Bonferroni correction. The ANOVA revealed a main effect of Condition, $F(3,79)=93.52, p$ $<.001$, Eta-squared $=0.79$. Follow-up t-tests revealed significant differences between the Honest condition and all other conditions (all ps $<.001$ ). The No Information condition differed significantly from all other conditions as well (all ps $<.001)$. There was no significant difference between the Dishonest and AIDS conditions, $(\mathrm{p}=.43$, $\mathrm{d}=.78)$. 


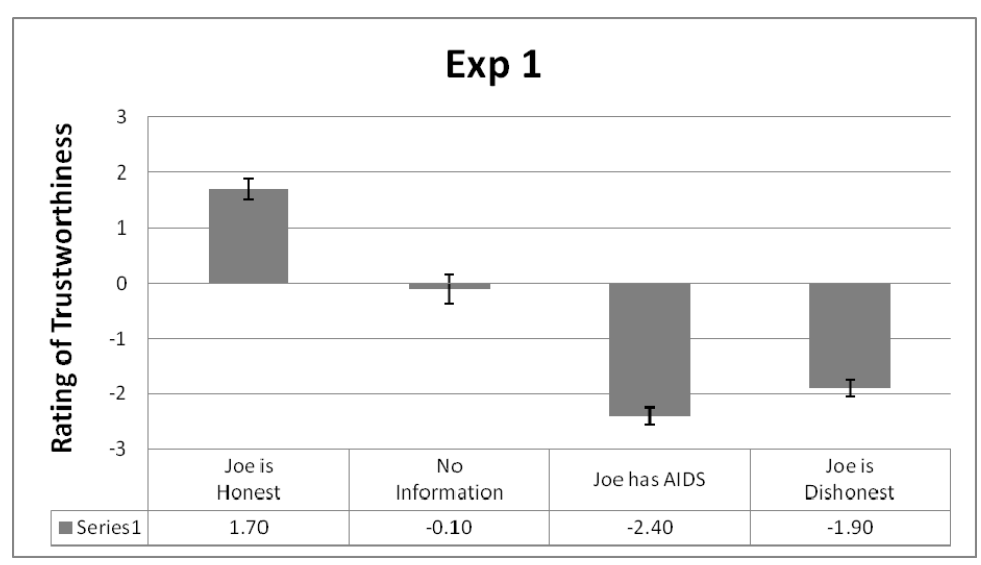

Figure 1. Data from Experiment 1. SE bars are included

\subsection{Discussion}

As expected, Joe was penalized in trustworthiness when he was described as having AIDS compared to conditions where there was no information about Joe or when he was described as an Honest person. We were somewhat surprised by how much the penalty entailed; that is, the results revealed that when Joe had AIDS, he was considered as untrustworthy as if he were described as being Dishonest. Apparently, the negative stigma associated with AIDS is so strong that it transfers directly to an entirely unrelated psychological construct such as trustworthiness. There is simply no rational reason for anyone to assume that a person with AIDS would be any less trustworthy than someone without AIDS. This finding is obviously dismaying and shows how AIDS sufferers are not only victimized by their disease and stigmas associated with it, but are also victimized in other unexpected ways, in this case, perceived trustworthiness.

\section{Experiment 2}

\subsection{Introduction}

In Experiment 1, we found that trust ratings of someone with AIDS were equivalent to trust ratings of someone who was dishonest. Because it is often the case that the situational information impacts trust ratings (e.g., Rice, et al., 2010) in Experiment 2 we set out to investigate the role of viral transmission on trust ratings. One reason for expanding the present research further in this direction is because gay men often face a great deal of stigma associated with HIV/AIDS (Chenard, 2007; Crandall, 1991; Herek \& Capitanio, 1999; Herek \& Glunt, 1988; Pryor, Reeder, \& Landau, 1999) and when someone is described as having AIDS, people often make the unfounded assumption that the disease was contracted via gay intercourse (Herek \& Capitanio, 1999; Herek \& Glunt, 1988; Pryor, Reeder, \& Landau, 1999).

In Experiment 2, we replicated the design of Experiment 1; however, we gave participants information about how the disease was exchanged, either by gay intercourse, heterosexual intercourse, or a blood transfusion. Because of the stigma associated with AIDS and the gay community, we predicted that an individual who contracted AIDS via a gay encounter would be trusted less than persons who had AIDS via other forms of transmission. Additionally, we were interested in determining if the low trust ratings in Experiment 1 were a result of participants implicitly assuming that the individual contracted AIDS via a gay encounter.

\subsection{Methods}

\subsubsection{Participants}

One hundred and twenty undergraduate students from a large southwestern university participated in the experiment for course credit. The mean age was $20.84(\mathrm{SD}=2.87)$.

\subsubsection{Materials, Stimuli, Procedure, and Design}

Experiment 2 was identical to Experiment 1 with one exception. Participants were given the following six scenarios about Joe (instead of 4): a) Joe is an Honest person; b) There is no information about Joe; c) Joe has AIDS which he contracted through sexual intercourse with a man; d) Joe has AIDS which he contracted through sexual intercourse with a woman; e) Joe has AIDS which he contracted via a blood transfusion; and f) Joe is a Dishonest person. 


\subsection{Results}

A one-way ANOVA was used to determine differences between the 6 conditions. Follow-up t-tests were subjected to a Bonferroni correction. The ANOVA revealed a main effect of Condition, $F(5,119)=38.24$, $p$ $<.001$, Eta-squared $=0.63$. Follow-up t-tests revealed significant differences between the Honest condition and all other conditions (all ps $<.001$ ). The No Information condition differed significantly from the AIDS (male-to-male sexual intercourse) and Dishonest conditions (all ps $<.001$ ), but not from the AIDS (transfusion) or AIDS (heterosexual sex), (all ps $>.05$ ). The Dishonest condition differed from all other conditions (all ps $<.001$ ), except the AIDS (male-to-male sexual intercourse) condition, $(\mathrm{p}=.45, \mathrm{~d}=0.39)$. The AIDS (male-to-male sexual intercourse) condition differed significantly from the other two AIDS conditions (all ps $<.001$ ). The AIDS (transfusion) condition differed from the AIDS (heterosexual sex) condition ( $\mathrm{p}=.017, \mathrm{~d}=$ $0.63)$.

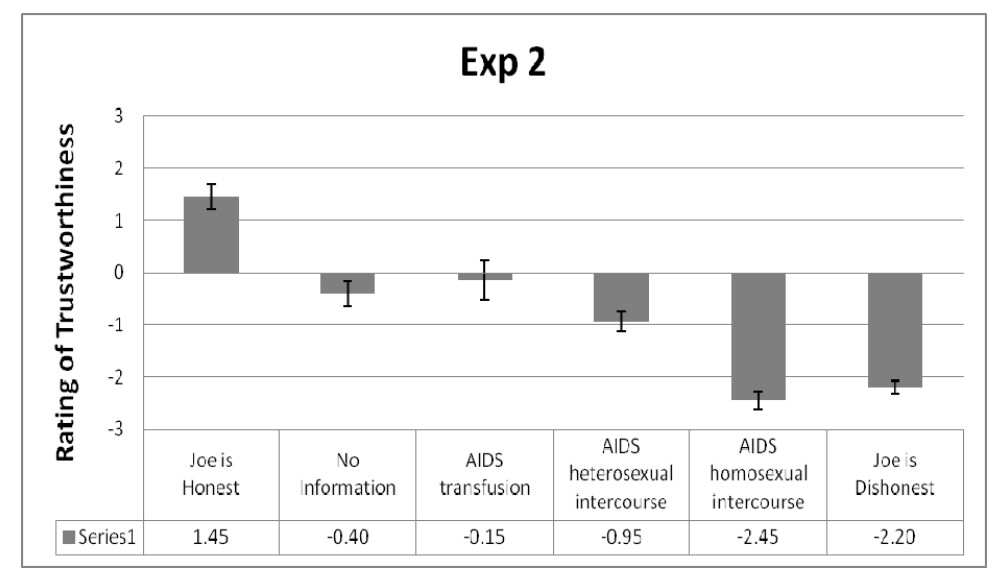

Figure 2. Data from Experiment 2. SE bars are included

\subsection{Discussion}

Once again, the results are in line with our predictions. When Joe was described as having AIDS, he was penalized in trustworthiness ratings across the board. Also, as expected, the role of viral transmission played a strong effect; when Joe was described as contracting AIDS via gay intercourse, he was again penalized as strongly as if he were described as Dishonest. These results are dismaying for a variety of reasons, not the least of which is that they implicitly show that in Experiment 1, participants were probably assuming that Joe contracted AIDS via gay intercourse even though that information was never given.

Another dismaying conclusion to this data is that the stigma associated with AIDS is not only connected to homosexuality; even when Joe was described as contracting AIDS via heterosexual intercourse, his trustworthiness ratings were still lower than when he contracted AIDS via a blood transfusion. The adage that AIDS sufferers are somehow responsible for their disease - unless they contract it via a blood transfusion, and then they are considered "victims"- appears to be showing up again in this data. Furthermore, this negative stigmatization of AIDS sufferers has crossed over into the completely unrelated psychological construct of trust.

\section{General Discussion}

The stigma associated with HIV/AIDS has been well established (Parker \& Aggleton, 2003; Herek, 2000; Sheehan, Lennon, \& McDevitt, 1989). For example, stigma has been shown to result in diminished value of individuals associated with the stigmatized group (Crocker, Major, \& Steele, 1998). Due to the importance of reducing stigma, research on stigmatization has been done using many methodologies. Self-report studies that assess AIDS patient's experiences with stigmatization (Hergovich, Ratky, \& Stollreiter, 2003; Berger, Ferrans, \& Lashley, 2001) as well as studies examining the general population's view of AIDS patients (Crandall \& Coleman, 1992; Kalichman, Simbayi, Cloete, Mthembu, Mkhonta, \& Ginindza, 2009) have been conducted. From both perspectives, research has investigated stigmatization by examining dimensions such as character flaws, disgust, inferiority, rejection, blame, and discrimination. The goal of the current study was to examine a different psychological construct, namely, the character trait of trustworthiness in people who are diagnosed with AIDS. Whereas negative attitudes toward individuals with the disease have been established, judgments about the trustworthiness of AIDS patients have not. 
In two experiments, the current research examined how people judged the trustworthiness of others when provided with information about an AIDS diagnosis. In Experiment 1, participants were told that an undergraduate student named Joe was either honest, dishonest, had AIDS, or no information was given. Shockingly, results showed that the target described as having AIDS was judged to be as untrustworthy as the target described as being dishonest. These results suggest that people in general view individuals with AIDS as less trustworthy even though there is no logical reason for this conclusion to be made.

Experiment 2 expanded on Experiment 1 by examining whether the method of viral transmission resulted in changes in trustworthiness. The target individual was described as being either honest, dishonest, or no information was provided as in the first experiment. However, in the second experiment, the target with AIDS was described as having contracted the disease through heterosexual sex, through male-to-male sexual intercourse, or though a blood transfusion. When the target was described as having contracted the disease through a blood transfusion, judgments of trustworthiness were not significantly different from having no information about the target. Surprisingly, however, when the target was described as having contracted AIDS through heterosexual sex, he was judged to be less trustworthy than the transfusion group. Even more remarkable was the result that the target described as contracting AIDS through male-to-male sexual intercourse was judged to be just as untrustworthy as the dishonest target. These results suggest that there seems to be an inherent distrust of people with AIDS, especially those who acquired the disease through male-to-male sexual intercourse.

Furthermore, when we compare the results from Experiment 2 to the results of the first experiment, a disturbing trend becomes apparent. Given the similar ratings between the AIDS target in Experiment 1 and the target acquiring AIDS through male-to-male sexual intercourse in Experiment 2, we believe that the lowered ratings of trust for the AIDS target in Experiment 1 are at least partially accounted for by participant's assumptions that the route of infection was through male-to-male sexual contact and/or that Joe was gay.

The question now becomes why the disturbing trends observed in the results occur. The stigma of HIV/AIDS has been studied in numerous ways and at least two reasons for the stigma have been identified. First of all, there are concerns related to contagion of the disease (Herek \& Capitanio, 1999). Due to the health concerns related to having a disease such as AIDS, individuals may see people with the disease as physically compromised and/or fear catching the disease. Secondly, there are concerns related to beliefs about improper lifestyles and actions related to the disease (Pryor, Reeder, \& Landau, 1999). Research has shown that people tend to believe that HIV/AIDS is associated with character traits and behaviors such as promiscuity (McCann, 1999), intravenous drug use, and homosexuality (Pryor, Reeder, \& Landau, 1999).

In fact, it has been shown that attitudes about gay individuals with HIV/AIDS are evaluated more negatively than heterosexual individuals with HIV/AIDS (Hergovich, Ratky, Stollreiter, 2003; Fish \& Rye, 1991; Kunkel \& Temple, 1992). We corroborated these findings in Experiment 2. Research has also found that gay individuals with AIDS are devalued even more than heterosexual individuals with AIDS (Leiker, Taub, \& Gast, 1995) and that homophobic individuals show less sympathy for people who are HIV-positive (Walters, 1997). Therefore, an added stigma seems to be apparent for gay individuals with AIDS.

Taking the previous research into consideration, we can see that social conceptions of the disease not only include the disease process, but also assumed behaviors, characteristics, and attitudes of individuals who are diagnosed with the disease. Social conceptions about HIV/AIDS likely influence judgments about people with the disease, even if there is no logical reason for the judgments. The current research suggests that inherent judgments of untrustworthiness and assumptions of homosexual identity are made about individuals with an AIDS status. Whereas the increased devaluing and negative attitudes towards gay individuals with HIV/AIDS have been established in previous research (Hergovich, Ratky, Stollreiter, 2003; Fish \& Rye, 1991; Kunkel \& Temple, 1992; Leiker, Taub, \& Gast, 1995; Walters, 1997), the decreased trustworthiness attributed to individuals with AIDS, especially gay individuals, has not been, to our knowledge, thoroughly researched.

Trust is the foundation for maintaining many different types of social relationships including interpersonal relationships (Stolle, 2002; Uslaner, 2002; Whiteley, 1999; Yamagishi \& Yamagishi, 1994), community relationships (Baier, 1986), business relationships (Zucker, 1986), and physician-patient relationships (Sohler, Fitzpatrick, Lindsay, Anastos, Cunningham, 2007; Mechanic, 1998; Doescher, Saver, Franks, \& Fiscella, 2000). Conversely, distrust has been shown to have negative social effects including non-cooperative behavior (Axelrod, 1984; Coleman, 1990) and in the healthcare sphere, inadequate treatment, decreased willingness to get tested, and decreased adherence to medication recommendations (Piette, Heisler, Krein, \& Kerr, 2005). Therefore, trust in individuals with HIV/AIDS is an important topic of research. 
So why is the character trait of trust devalued in individuals with HIV/AIDS even though there is no logical connection between having the disease and the trait of trustworthiness? It is possible that it is due to membership in a stigmatized group. Stigmatized groups have been shown to be devaluated compared to non-stigmatized groups (Crocker, Major, \& Steele, 1998). Therefore, stigmatized groups may be viewed as out-groups. Research has shown that there is inherent competition between groups resulting in a distrust of the out-group and a need to protect the in-group (Brewer, 2001; Fiske \& Ruscher, 1993; Insko, Schopler, Hoyle, Dardis, \& Graetz, 1990) Therefore, the stigma of AIDS likely creates an outgroup that diminishes trust even though a logical connection between having AIDS and untrustworthiness is not present. The added factor of homosexual identity likely further contributes to the outgroup status, especially among homophobic individuals. This distrust serves to further distance the relationships between individuals with AIDS and those who do not have the disease.

The finding of increased levels of untrustworthiness against individuals described as having AIDS compared to healthy controls is no doubt a disturbing trend. Due to stigma's propensity for negative consequences including but not limited to interference with disease prevention, diminished treatment seeking behavior, and diminished desire to get tested (Parker \& Aggleton, 2003), the need to find ways to reduce stigma is critical. Furthermore, there is evidence that the stigma associated with AIDS can become internalized and affect physical and mental health (Lee, Kochman, \& Sikkema, 2002; Crandall \& Coleman, 1992). Therefore, interventions that reduce stigma are of utmost importance in ensuring AIDS sufferers receive fair treatment in healthcare settings and in general. Interventions that address fostering trust may have success in diminishing the stigmatization of the disease in the future.

\subsection{Limitations and Future Directions}

Although this study provides important insight into the stigmatization of individuals with AIDS, there are some limitations. AIDS is not the only disease or disorder that is stigmatized. Mental illness and other physical illnesses may also carry similar stigmas. However, this study only examined one disease. Future research should examine multiple disorders including depression, anxiety, bipolar disorders, cancer, and chronic back pain to see if similar detriments to judgments of trustworthiness occur.

Furthermore, the current study only examined a single male target. However, it is likely that levels of stigmatization differ between genders and among different age groups. For example, women, children, and the elderly may not experience the same level of distrust due to conceptions that these groups are more fragile. Future studies should measure these variables.

Finally, the way a disease, illness, or disorder is described might have an impact on judgments of trust. For example, stating that a target was "diagnosed with," "claims to have," or "tells you s/he has" a certain disease could make a difference in levels of blame and distrust ascribed to the patient. Future research should examine these factors.

\subsection{Conclusions}

The current research examined the stigma of the AIDS disease using the specific character trait of trustworthiness. In two experiments, it was shown that a target individual who was described as having AIDS was judged to be as untrustworthy as a target individual who was described as dishonest. Furthermore, the second experiment showed that a target described as having acquired the HIV virus through male-to-male sexual intercourse was judged to be significantly less trustworthy than a target described as having acquired the virus through a blood transfusion or heterosexual sex. The results of these two studies suggest that individuals with AIDS are perceived as untrustworthy likely due to being part of a stigmatized outgroup. Additionally, it was implied that when the method of acquiring the disease is unknown, people tend to assume that it was through male-to-male sexual intercourse. Judgments of distrust and assumptions about sexual orientation seem to further contribute to the stigmatization and negative attitudes toward people with HIV/AIDS. Interventions focusing on fostering trust may help alleviate the negative consequences of stigmatization.

\section{Acknowledgements}

J.S. was supported in part by the National Science Foundation (NSF) through the Graduate STEM Fellows in K-12 Education (GK-12) Program, under grant number DGE-0947465.

\section{References}

Ajzen, I., \& Fishbein, M. (1980). Understanding attitudes and predicting social behavior. Englewood Cliffs, NJ: Prentice Hall.

Anderson, C., \& Thompson, L. (2004). Affect from the top down: How powerful individuals' positive affect 
shapes negotiations. Organizational Behavior and Human Decision Processes, 95, 125-139. http://dx.doi.org/10.1016/j.obhdp.2004.05.002

Arden-Close, E., Moss-Morris, R., Dennison, L., Bayne, L., \& Gidron, Y. (2010). The couples' illness communication scale (CICS): Development and evaluation of a brief measure assessing illness-related couple communication. British Journal of Health Psychology, 15, 543-559. http://dx.doi.org/10.1348/135910709X476972

Axelrod, R. (1984). The evolution of cooperation. New York: Basic Books.

Bach, P. B., Pham, H. H., Schrag, D., Tate, R. C., \& Hargraves, J. L. (2004). Primary Care Physicians Who Treat Blacks and Whites. The New England Journal of Medicine, 351, 575-584. http://dx.doi.org/10.1056/NEJMp048143

Baier, A. C. (1994). Moral prejudices. Cambridge, MA: Harvard University Press.

Berger, B. E., Ferrans, C., \& Lashley, F. R. (2001). Measuring stigma in people with HIV: Psychometric assessment of the HIV Stigma Scale. Research in Nursing and Health, 24, 518-529. http://dx.doi.org/10.1002/nur.10011

Berscheid, E., \& Walster, E. (1974). Physical attractiveness. In L. Berkowitz (Ed.), Advances in experimental social psychology (Vol. 6, pp. 157-215). New York: Academic Press.

Bresnahan, M., \& Zhuang, J. (2011). Exploration and validation of the dimensions of stigma. Journal of Health Psychology, 16, 421-429. http://dx.doi.org/10.1177/1359105310382583

Brewer, M. B. (2001). Ingroup identification and intergroup conflict: When does ingroup love become outgroup hate? In R. D. Ashmore, L. Jussim, \& D. Wilder (Eds.), Social Identity, Intergroup Conflict and Conflict Reduction (Vol. 3, pp. 17-36). New York: Oxford University Press.

Butler, J. K. (1991). Toward understanding and measuring conditions of trust: Evolution of a conditions of trust inventory. Journal of Management, 17, 643-663. http://dx.doi.org/10.1177/014920639101700307

Carpenter, C. J. (2010). A meta-analysis of the effectiveness of health belief model variables in predicting behavior. Health Communication, 25, 661-669. http://dx.doi.org/10.1080/10410236.2010.521906

Carter, N. L., \& Weber, J. (2010). Not Pollyannas: Higher generalized trust predicts lie detection ability. Social Psychological and Personality Science, 1, 274-279. http://dx.doi.org/10.1177/1948550609360261

Chenard, C. (2007). The impact of stigma on the self-care behaviors of HIV-positive gay men striving for normalcy. Journal of the Association of Nurses in AIDS Care, 18, 23-32. http://dx.doi.org/10.1016/j.jana.2007.03.005

Choi, J. N. (2006). Multilevel and crosslevel effects of workplace attitudes and group membership. Human Performance, 19, 383-402. http://dx.doi.org/10.1207/s15327043hup1904_4

Coleman, J. S. (1990). Foundations of social theory. Cambridge, MA: Belknap Press of Harvard University Press.

Crandall, C. S. (1991). Multiple stigma and AIDS: Illness stigma and attitudes towards gays and IV drug users in AIDS-related stigmatization. Journal of Community and Applied Social Psychology, 1, 165-172. http://dx.doi.org/10.1002/casp.2450010210

Crandall, C. S., \& Coleman, R. (1992). AIDS-related stigmatization and the disruption of social relationships. Journal of Social and Personal Relationships, 9, 163-177. http://dx.doi.org/10.1177/0265407592092001

Crocker, J., \& Major, B. (1989). Social stigma and self-esteem: The self-protective properties of stigma. Psychological Review, 26, 608-630. http://dx.doi.org/10.1037//0033-295X.96.4.608

Crocker, J., Cornwell, B., \& Major, B. (1993). The stigma of overweight: Affective consequences of attributional $\begin{array}{lllll}\text { ambiguity. Journal of Personality and Social Psychology, 64, } & \text { 60-70. }\end{array}$ http://dx.doi.org/10.1037/0022-3514.64.1.60

Crocker, J., Major, B., \& Steele, C. (1998). Social stigma. In D. T. Gilbert, \& S. T. Fiske (Eds.), The handbook of social psychology (Vol. 2, pp. 504-553). New York: McGraw-Hill.

Crocker, J., Voelkl, K., Testa, M., \& Major, B. (1991). Social stigma: The affective consequences of attributional ambiguity. Journal of Personality and Social Psychology, 60, 218-228. http://dx.doi.org/10.1037/0022-3514.60.2.218 
Deutsch, M. (1960). Trust, trustworthiness, and the F scale. Journal of Abnormal and Social Psychology, 61, 138-140. http://dx.doi.org/10.1037//0022-3514.60.2.218

Dixon, S. R., \& Wickens, C. D. (2006). Automation unreliability in unmanned air vehicle control: a reliance/compliance model of automation dependence in high workload. Human Factors, 48, 474-486. http://dx.doi.org/10.1518/001872006778606822

Dixon, S. R., Wickens, C. D., \& McCarely, J. M. (2007). On the independence of compliance and reliance: Are automation false alarms worse then misses?. Human Factors, 49, 564-572. http://dx.doi.org/10.1518/001872007X215656

Doescher, M. P., Saver, B. G., Franks, P., \& Fiscella, K. (2000). Racial and ethnic disparities in perceptions of physician style and trust. Archives of Family Medicine, 9, 1156-1163. http://dx.doi.org/10.1001/archfami.9.10.1156

Farina, A. (1982). The stigma of mental disorders. In A. G. Miller (Ed.), In the eye of the beholder: Contemporary approaches to stereotyping (pp. 305-363). New York: Praeger.

Fish, T. A., \& Rye, B. J. (1991). Attitudes toward a gay or heterosexual person with AIDS. Journal of Applied Social Psychology, 21, 651-667. http://dx.doi.org/10.1111/j.1559-1816.1991.tb00541.x

Fishbein, M., \& Ajzen, I. (1975). Belief, Attitude, Intention, and Behavior. New York: Wiley.

Fiske, S. T., \& Ruscher, J. B. (1993). Negative interdependence and prejudice: Whence the affect?. In D. M. Mackie, \& D. L. Hamilton (Eds.), Affect, cognition, and stereotyping: Interactive processes in group perception (pp. 239-268). San Diego: Academic Press.

Gore-Felton, C., Koopman, C., Spiegel, D., Vosvick, M., Brondino, M., \& Winningham, A. (2006). Effects of quality of life and coping on depression among adults living with HIV/AIDS. Journal of Health Psychology, 11, 711-729. http://dx.doi.org/10.1177/1359105306066626

Gore-Felton, C., Koopman, C., Turner-Cobb, J.M., Duran, R., Israelski, D., \& Spiegel, D. (2002). The influence of social support, coping and mood on sexual risk behavior among HIV-positive men and women. Journal of Health Psychology, 7, 713-722. http://dx.doi.org/10.1177/1359105302007006874

Harris, M. B., Harris, R. J., \& Bochner, S. (1982). Fat four-eyed and female: Stereotypes of obesity glasses and gender. Journal of Applied Social Psychology, $12, \quad$ 503-516. http://dx.doi.org/10.1111/j.1559-1816.1982.tb00882.x

Henshaw, E. J., \& Freedman-Doan, C. R. (2009). Conceptualizing mental health care utilization using the health belief model. Clinical Psychology: Science and Practice, 16, 420-439. http://dx.doi.org/10.1111/j.1468-2850.2009.01181.x

Herek, G. M. (2000). The social construction of attitudes: Functional consensus and divergence in the US public's reactions to AIDS. In G. R. Maio, \& J. M. Olson (Eds.), Why we evaluate: Functions of attitudes (pp. 325-364). Mahwah, NJ: Erlbaum.

Herek, G. M., \& Capitanio, J. P. (1999). AIDS stigma and sexual prejudice. American Behavioral Scientist, 42 , 1130-1147. http://dx.doi.org/10.1177/0002764299042007006

Herek, G. M., \& Glunt, E. K. (1988). An epidemic of stigma: Public reactions to AIDS. American Psychologist, 43, 886-891. http://dx.doi.org/10.1037//0003-066X.43.11.886

Hergovich, A., Ratky, E., \& Stollreiter, M. (2003). Attitudes toward HIV-positives in dependence on their sexual orientation. Swiss Journal of Psychology, 62, 37-44. http://dx.doi.org/10.1024//1421-0185.62.1.37

Hutchinson, A. B., Corbie-Smith, G., Thomas, S. B., Mohanan, S., \& del Rio, C. (2004). Understanding the patient's perspective on rapid and routine HIV testing in an inner-city urgent care center. AIDS Education and Prevention, 16, 101-114.

Insko, C. A., Schopler, J., Hoyle, R. H., Dardis, G. J., \& Graetz, K. A. (1990). Individual-group discontinuity as a function of fear and greed. Journal of Personality and Social Psychology, 58, 68-79. http://dx.doi.org/10.1037//0022-3514.58.1.68

Jones, E. E., Farina, A., Hastorf, A. H., Markus, H., Miller, D. T., \& Scott, R. A. (1984). Social stigma: The psychology of marked relationships. New York: W. H. Freeman.

Kalichman, S. C., Simbayi, L. C., Cloete, A., Mthembu, P. P., Mkhonta, R. N., \& Ginindza, T. (2009). Measuring AIDS stigmas in people living with HIV/AIDS: the Internalized AIDS-Related Stigma Scale. AIDS Care, 


\section{1, 87-93. http://dx.doi.org/10.1080/09540120802032627}

Keller, D., \& Rice, S. (2010). System-wide versus component-specific trust using multiple aids. Journal of General Psychology, 137, 114-128. http://dx.doi.org/10.1080/00221309.2010.499397

Kunkel, L. E., \& Temple, L. L. (1992). Attitudes toward AIDS and gays: gender, marital status, and religion. $\begin{array}{lllll}\text { Journal of Applied Social } & \text { Psychology, } & \text { 22, }\end{array}$ http://dx.doi.org/10.1111/j.1559-1816.1992.tb00940.x

Lee, R. S., Kochman, A., \& Sikkema, K. J. (2002). Internalized stigma among people living with HIV-AIDS. AIDS and Behavior, 6, 309-319. http://dx.doi.org/10.1023/A:1021144511957

Leiker, J. J., Taub, D. E., \& Gast, J. (1995). The stigma of AIDS: persons with AIDS and social distance. Deviant Behavior, 16, 333-351. http://dx.doi.org/10.1080/01639625.1995.9968007

Lewicki, R. J., \& Bunker, B. B. (1995). Trust in relationships: A model of development and decline. In B. B. Banker, \& J. Z. Rubin (Eds.), Conflict, cooperation, and justice (pp. 133-173). San Francisco, CA: Jossey-Bass.

Lewicki, R. J., \& Weithoff, C. (2000). Trust, trust development, and trust repair. In M. Deutsch, \& P. T. Coleman (Eds.), Handbook of conflict resolution: Theory and practice (pp. 86-107). San Francisco: Jossey-Bass.

Link, B. G., \& Phelan, J. C. (2001). Conceptualizing stigma. Annual Review Sociology, 27, 363-85. http://dx.doi.org/10.1146/annurev.soc.27.1.363

Mahjan, A. P., Sayles, J. N., Patel, V. A., Remien, R. H., Ortiz, D., Szekeres, G., \& Coates, J. (2008). Stigma in the HIV/AIDS epidemic: A review of the literature and recommendations for the way forward. AIDS, 22, 67-79. http://dx.doi.org/10.1097/01.aids.0000327433.90419.61

McAllister, D. J. (1995). Affect- and cognition-based trust as foundations for interpersonal cooperation in organizations. Academy of Management Journal, 38, 24-59. http://dx.doi.org/10.2307/256727

McCann, T. V. (1999). Reluctance amongst nurses and doctors to care for and treat patients with HIV/AIDS. AIDS Care, 11, 355-359. http://dx.doi.org/10.1080/09540129947974

Mechanic, D. (1998). The functions and limitations of trust in the provision of medical care. Journal of Health Politics, Policy and Law, 23, 199-213. http://dx.doi.org/10.1007/BF02344933

Messick, D. M. (1983). Individual adaptations and structural change as solutions to social dilemmas. Journal of Personality and Social Psychology, 44, 294-309. http://dx.doi.org/10.1037//0022-3514.44.2.294

Miller, P., \& Rempel, J. (2004). Trust and partner-enhancing attributions in close relationships. Personality and Social Psychology Bulletin, 30, 695-705. http://dx.doi.org/10.1177/0146167203262803

Molero, F., Fuster, M. J., Jetten, J., \& Moriano, J. A. (2011). Living with HIV/AIDS: A psychosocial perspective on coping with prejudice and discrimination. Journal of Applied Social Psychology, 41, 609-626. http://dx.doi.org/10.1111/j.1559-1816.2011.00729.x

Newman, J. (1976). Faculty attitudes toward handicapped students. Rehabilitation Literature, 37, 194-197.

Nugent, P. D., \& Abolafia, M. Y. (2006). The creation of trust through interaction and exchange: The role of consideration in organizations. Group \& Organization Management, 31, 628-650. http://dx.doi.org/10.1177/1059601106286968

O'Cleirigh, C., Ironson, G., Fletcher, M. A., \& Schneiderman, N. (2008). Written emotional disclosure and processing of trauma are associated with protected health status and immunity in people living with HIV/AIDS. British Journal of Health Psychology, 13, 81-84. http://dx.doi.org/10.1348/135910707X250884

Offe, C. (1999). How can we trust our fellow citizens? In M. Warren (ed.), Democracy and trust. Cambridge: Cambridge University Press.

Parker, R., \& Aggleton, P. (2003). HIV and AIDS-related stigma and discrimination: A conceptual framework and implications for action. Social Science and Medicine, 57, 13-24. http://dx.doi.org/10.1016/S0277-9536(02)00304-0

Piette, J. D., Heisler, M., Krein, S., \& Kerr, E. A. (2005). The role of patient-physician trust in moderating medication nonadherence due to cost pressures. Archives of Internal Medicine, 165, 1749-1755. http://dx.doi.org/10.1001/archinte.165.15.1749

Preston, D. B., D’Augelli, A. R., Kassab, C. D., \& Starks, M. T. (2007). The relationship of stigma to the sexual 
risk behavior of rural men who have sex with men. AIDS Education Preview, 19, 218-230. http://dx.doi.org/10.1521/aeap.2007.19.3.218

Pryor, J. B., Reeder, G. D., \& Landau, S. (1999). A social psychological analysis of HIV-related stigma. American Behavioral Scientist, 42, 1189-1207. http://dx.doi.org/10.1177/0002764299042007010

Putnam, R. D. (2000). Bowling alone: The collapse and revival of American community. New York: Simon \& Schuster.

Rice, S., \& McCarley, J. (in press). Effects of response bias and judgment framing on operator use of an automated aid in a target detection task. Journal of Experimental Psychology: Applied.

Rice, S. (2009). Examining single and multiple-process theories of trust in automation. Journal of General Psychology, 136, 303-319. http://dx.doi.org/10.3200/GENP.136.3.303-322

Rice, S., Trafimow, D., Clayton, K., \& Hunt, G. (2008). Impact of the contrast effect on trust ratings and behavior with automated systems. Cognitive Technology Journal, 13, 30-41.

Rice, S., Trafimow, D., Hunt, G., \& Sandry, J. (2010). Generalizing Kant's distinction between perfect and imperfect duties to trust in different situations. Journal of General Psychology, 137, 20-36. http://dx.doi.org/10.1080/00221309.2010.484447

Rosen, B. (1977). Influence of subordinate characteristics on trust and use of participative decision strategies in a management simulation. Journal of Applied Psychology, 62, 628-631.

Rosenstock, I. M. (1966). Why people use health services. Milbank Memorial Fund Quarterly, 44, 94-127.

Rosenstock, I. M. (1974). Historical origins of the health belief model. Health Education Monographs, 2, 328-335.

Rosenstock, I. M., Strecher, V. J., \& Becker, M. H. (1988). Social learning theory and the health belief model. Health Education Quarterly, 15, 175-183. http://dx.doi.org/10.1177/109019818801500203

Rotte, K., Chandrashekaran, M., Tax, S. S., \& Grewal, R. (2006). Forgiven but not forgotten: Covert uncertainty in overt responses and the paradox of defection-despite-trust. Journal of Consumer Psychology, 16, 283-294. http://dx.doi.org/10.1207/s15327663jcp1603_10

Rotter, J. B. (1971). Generalized expectancies for interpersonal trust. American Psychologist, 443-452.

Rotter, J. B. (1980). Interpersonal Trust, Trustworthiness, and Gullibility. American Psychologist, 35, 1-7.

Sapp, G. G. (2002). Incomplete knowledge and attitude-behavior inconsistency. Social Behavior and Personality, 30, 37-44. http://dx.doi.org/10.2224/sbp.2002.30.1.37

Schrimshaw, E. W., \& Siegel, K. (2003). Perceived barriers to social support from families and friends among older adults with HIV/AIDS. Journal of Health Psychology, 8, 738-752. http://dx.doi.org/10.1177/13591053030086007

Sheehan, E. P., Lennon, R., \& McDevitt, T. (1989). Reactions to AIDS and other illnesses: Reported interactions in the workplace. Journal of Psychology, 123, 525-536.

Simbayi, L. C., Kalichman, S. C., Strebel, A., Cloete, A., Henda, N., \& Mqeketo, A. (2007). Disclosure of HIV status to sex partners and sexual risk behaviours among HIV-positive men and women, Cape Town, South Africa. Sex Transmission Infection, 83, 29-34. http://dx.doi.org/10.1016/j.socscimed.2007.01.006

Sohler, N. L., Fitzpatrick, L. K., Lindsay, R. G., Anastos, K., \& Cunningham, C. O. (2007). Does patient-provider racial/ethnic concordance influence ratings of trust in people with HIV infection?. AIDS Behavior, 11, 884-896. http://dx.doi.org/10.1007/s10461-007-9212-0

Stolle, D. (2002). Trusting strangers: The concept of generalized trust in perspective. Austrian Journal of Political Science, 31, 397-412.

Sztompka, P. (1997). Trust, Distrust and the Paradox of Democracy. Wissenschaftszentrum Berlin für Sozialforschung. Retrieved from http://skylla.wz-berlin.de/pdf/1997/p97-003.pdf

Uslaner, E. M. (2002). The moral foundations of trust. Cambridge: Cambridge University Press.

Vanable, P. A., Carey, M. P., Blaire, D. C., \& Littlewood, R. A. (2006). Impact of HIV related stigma on health behaviors and psychological adjustment among HIV-positive men and women. AIDS Behavior, 10, 473-482. http://dx.doi.org/10.1007/s10461-006-9099-1

Walters, A. S. (1997). The influence of homophobia in HIV/AIDS education. Journal of Psychology and Human 
Sexuality, 9, 17-38. http://dx.doi.org/10.1300/J056v09n02_02

Weber, J., Malhotra, D., \& Murnighan, J. (2005). Normal acts of irrational trust: Motivated attributions and the trust development process. Research in organizational behavior: An annual series of analytical essays and critical reviews (Vol. 26, pp. 75-101).

Whetten, K., Leserman, J., Whetten, R., Ostermann, J., Thielman, N., Swartz, M., \& Stangl, D. (2006). Exploring trust in care providers and the government as a barrier to health service use. American Journal Public Health, 96, 716-721. http://dx.doi.org/10.2105/AJPH.2005.063255

Whetten, K., Reif, S., Whetten, R., \& Murphy-McMillan, L. K. (2008). Trauma, Mental Health, Distrust, and Stigma Among HIV-Positive Persons: Implications for Effective Care. Psychosomatic Medicine, 70, 531-538. http://dx.doi.org/10.1097/PSY.0b013e31817749dc

Whiteley, P. (1999). The origins of social capital. In J. W. van Deth et al. (ed.), Social capital and European democracy. London: Routledge.

Wrightsman, L. S. (1966). Personality and attitudinal correlates of trusting and trustworthy behaviors in a two-person game. Journal of Personality and Social Psychology, 4, 328-332. http://dx.doi.org/10.1037/h0023655

Yamagishi, T., \& Yamagishi, M. (1994). Trust and commitment in the United States and Japan. Motivation and Emotion, 18, 129-166. http://dx.doi.org/10.1007/BF02249397

Zucker, L. G. (1986). Production of trust: Institutional sources of economic structure, 1840-1920. Research in Organizational Behaviour, 8, 53-111. 